\title{
MECHANISMS OF COASTAL DIKE FAILURE INDUCED BY THE GREAT EAST JAPAN EARTHQUAKE TSUNAMI
}

\author{
Fuminori Kato $^{1}$, Yoshio Suwa ${ }^{1}$, Kunihiro Watanabe ${ }^{1}$ and Satoshi Hatogai ${ }^{1}$
}

\begin{abstract}
Based on the results of field surveys, coastal dike failures caused by the Great East Japan Earthquake were classified into eight patterns. The results of hydraulic model experiments related to major failure patterns reinforced the proposed failure processes. In addition, the aggregated length of each failure pattern showed that failure from scouring at the landward toe is the dominant failure pattern.
\end{abstract}

Keywords: tsunami; coastal dike; scour; failure mechanism; overflow

\section{INTRODUCTION}

The Great East Japan Earthquake generated a massive tsunami in the northwestern Pacific Ocean on March 11, 2011. The tsunami overtopped dikes and seawalls along Japan's eastern shoreline, and broke dikes and seawalls about $190 \mathrm{~km}$ long in the three most affected prefectures: Iwate, Miyagi and Fukushima.

Japan has constructed armored dikes and concrete seawalls along the shoreline since the typhooninduced storm surge disaster in 1953 and the Chilean Earthquake tsunami in 1960. Generally, the crown and slopes of these coastal dikes are covered with concrete. Coastal dike height is determined by considering the necessary height for storm surges and tsunami, often using data on tsunami of the past 100 years as a design reference.

The mechanisms behind the failure of concrete-armored dikes and seawalls caused by tsunami have not yet been fully elucidated. Shuto (2009) collected damage examples from the 1933 Showa Great Sanriku Tsunami and the 1960 Chilean Tsunami, and showed the effects of tsunami overflow on coastal embankment and toe erosion caused by backwash as damage patterns. Nishimura and Horikawa (1979) and Noguchi et al. (1997) found some correlation between the scour depth in front of coastal revetments and the overflow depth in the tsunami drawdown process. Kato et al. (2007) showed patterns of coastal dike failure due to tsunami including destruction of the parapet during tsunami runup and backwash, and scouring at the landward slope and seaward toe. As for the Great East Japan Earthquake, failure of coastal dikes was reported in previous papers (Mikami et al., 2012; Ogasawara et al., 2012).

To clarify the mechanisms of coastal dike failure, we conducted field surveys just after the earthquake as well as hydraulic model experiments related to major failure patterns. In addition, we proposed resilient structures for coastal dikes based on the failure mechanisms.

\section{METHODS}

\section{Field Surveys}

Field surveys on coastal dike failure were conducted along the shoreline in Iwate, Miyagi, and Fukushima Prefectures between March and May 2011 (Fig. 1). Tsunami height near the shoreline and the shape of collapsed coastal dikes were measured in the surveys.

We also obtained the officially recorded data on dike and tsunami height for each coast where the tsunami surged over the coastal dike between Aomori Prefecture and Chiba Prefecture.

\section{Hydraulic Model Experiments}

To understand the failure mechanisms of the coastal dikes, hydraulic model experiments were performed in a channel $40 \mathrm{~m}$ long, $2 \mathrm{~m}$ wide, and $1.5 \mathrm{~m}$ high. The scale of the experiments was $1 / 25$. In these experiments, the overflow process was imitated by discharging water from pumps. A wave generator was not used, because the wave length of the Great East Japan Earthquake Tsunami exceeded the capacity of our wave tank. The channel was equipped with pumps and a bulb to control the discharge. The maximum discharge of the pumps was $0.6 \mathrm{~m}^{3} / \mathrm{s}$. As shown in Fig. 2, the side wall was transparent glass, allowing us to observe the flow and scouring near the dike.

\footnotetext{
${ }^{1}$ National Institute for Land and Infrastructure Management, 1 Asahi, Tsukuba, Ibaraki 305-0804, Japan
} 


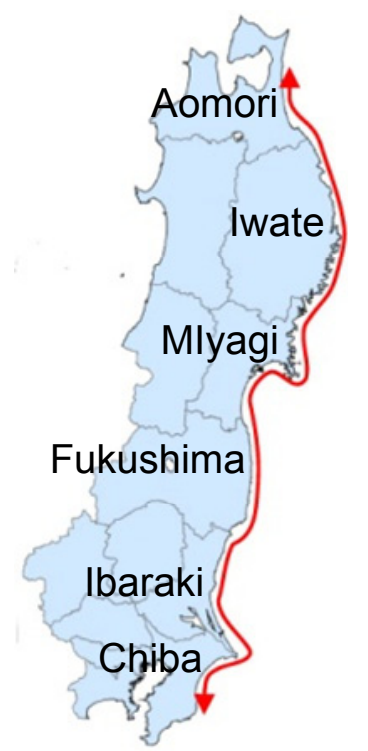

Figure 1. Extent of inundated coastline in the Great East Japan Earthquake.

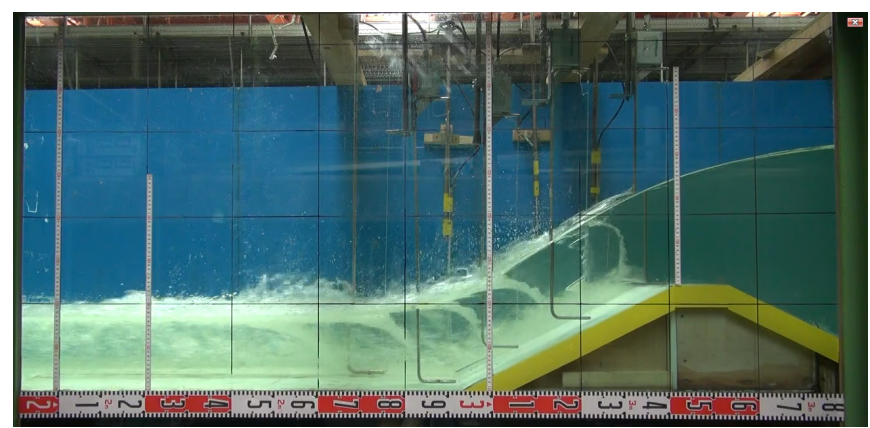

Figure 2. Snapshot of hydraulic model experiments.

\section{MECHANISMS OF COASTAL DIKE FAILURE}

\section{Failure Patterns}

Based on the results of field surveys and hydraulic model experiments, the failure of coastal dikes and seawalls was classified into the following eight patterns:

1. Failure from scouring at landward toe

The landward toe of the coastal dike was scoured in many areas where the dike or seawall was not completely washed away. For example, as shown in Fig. 3, a ditch had formed on the landward side of the coastal dike, stretching in the longshore direction on Kabasaki Coast, Miyagi Prefecture. Kato et al. (2012) also showed some examples in Iwate Prefecture where tsunami runup induced scouring at the landward toe, resulting in the destruction of landward armor and the dike body.

Figure 4 shows the average scour width on the landward side of coastal dikes in the southern part of the Sendai Plain, Miyagi Prefecture. Scour width was measured based on data obtained by airborne laser scanner after the earthquake. Along the sandy coast of about $40 \mathrm{~km}$ long, the scour width was about $30 \mathrm{~m}$ on average. A relatively large scour width was observed in the southern part where the proportion of completely failed coastal dikes was higher.

The results of the hydraulic model experiments helped us to understand the scouring process at the landward toe of the coastal dikes. Figure 5 shows the cross-sectional shape of the sandy bed landward of the coastal dike after two minutes of overflow in the experimental channel. The discharge was controlled in the upstream to obtain the targeted overflow depth. The height of the model dike was $36 \mathrm{~cm}$, corresponding to a prototype height of $9 \mathrm{~m}$. The grain size of the movable bed landward of the coastal dike was $0.25 \mathrm{~mm}$. The landward slope was $1 / 2$ or $1 / 3$, and the overflow depth $\mathrm{h}$ was $4,8,12$, 24 , or $40 \mathrm{~cm}$. The scour depth and scour width tended to increase with overflow depth. Although the 
height of the model dike in prototype scale is higher than the coastal dike in the southern part of the Sendai Plain (T.P. 3.6-7.2 m), the scour width of the experiment in the case of $\mathrm{h}=24 \mathrm{~cm}(6 \mathrm{~m}$ in prototype scale) is roughly the same as the scour width as shown in Fig. 3.

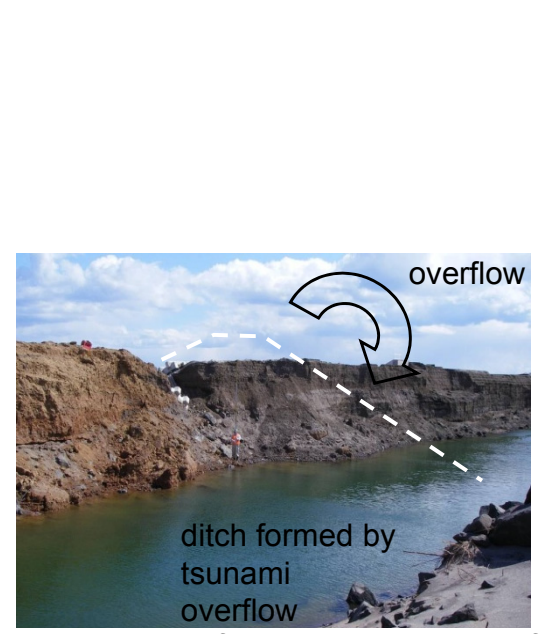

Figure 3. Ditch formed by tsunami overflow (Kabasaki Coast, Miyagi Prefecture).

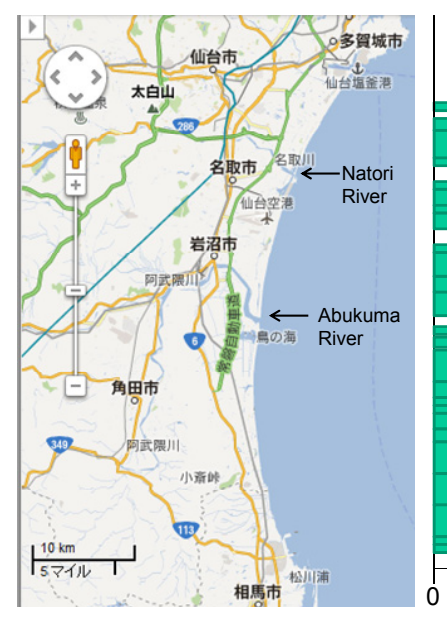

Figure 4. Longshore distribution of average scour width in the southern part of the Sendai Plain.

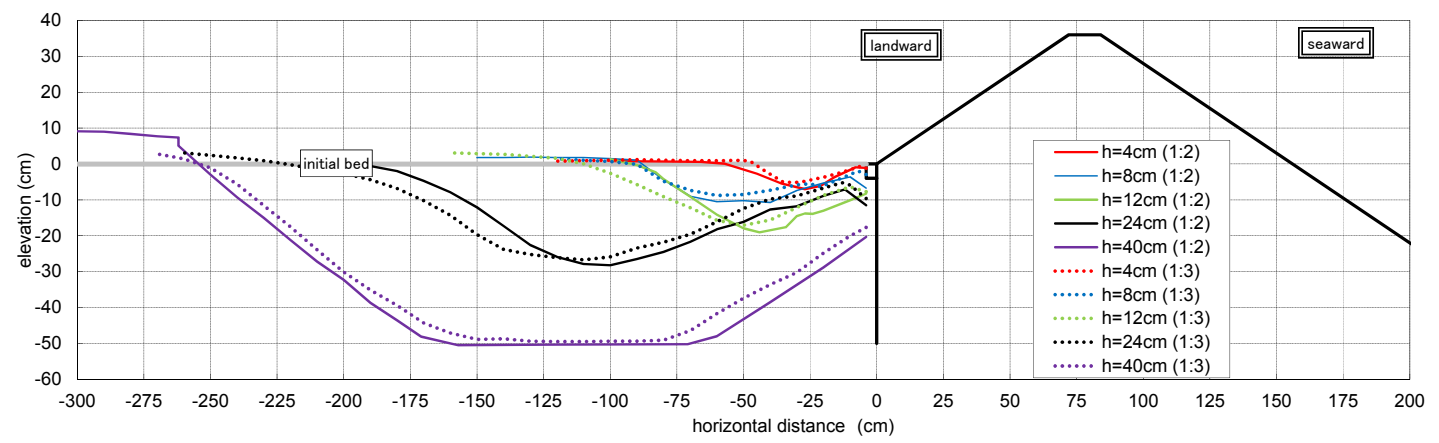

Figure 5. Scouring at the landward toe in hydraulic model experiments.

Based on the results of field surveys and physical experiments, the process of failure from scouring at the landward toe can be summarized as shown in Fig. 6. Landward armor of the coastal dike floated away after scouring at the landward toe. With no landward armor, the dike body was easily washed away.

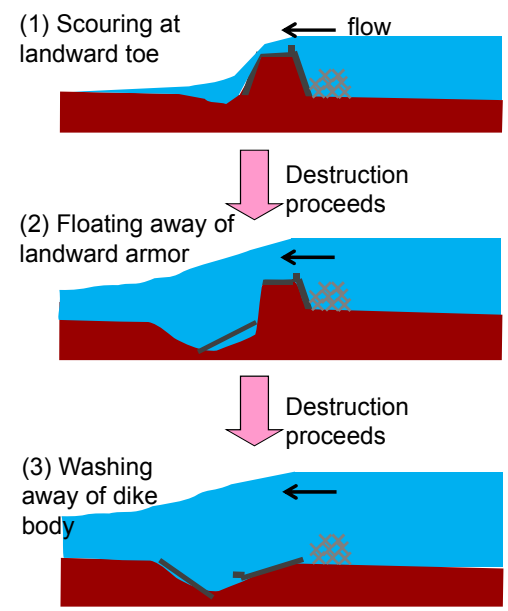

Figure 6. Failure process originating from scouring at landward toe. 
2. Failure from the crown or the top of landward armor

The second pattern is failure from the crown or the top of the landward armor. Failure of the landward slope or crown armor was observed even where the landward toe was not scoured, as shown in Fig. 7. On the Kanahama Coast (left photo in Fig. 7), the upper part of the landward armor floated away, while no obvious scouring was seen on the landward side of the coastal dike. On the Omagari Coast (right photo in Fig. 7), the crown armor was washed away, but there was no damage to the seaward and landward armor.
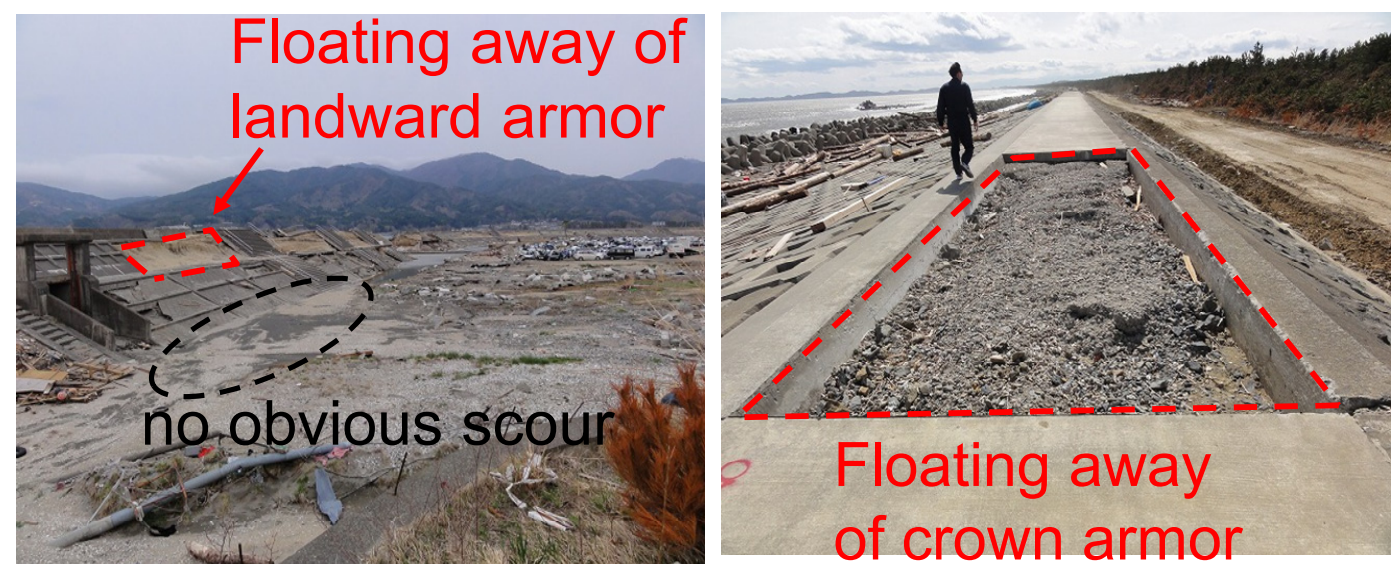

Figure 7. Examples of failure originating from scouring at landward toe (left: Kanahama Coast, Iwate prefecture; right: Omagari Coast, Miyagi Prefecture).

One of the main factors related to this pattern is negative force acting on the landward armor during tsunami runup. This negative force might be caused by fast flow at the top of the landward slope. Figure 8 shows the cross-shore distribution of water levels and piezometric heads in the physical experiments. The height of the model dike was $24 \mathrm{~cm}$. Overflow depth was $40 \mathrm{~cm}$ in the upper figure and $4 \mathrm{~cm}$ in the lower figure. At the top of the landward slope, the piezometric head was below the height of the dike surface in both cases, indicating the occurrence of negative pressure.

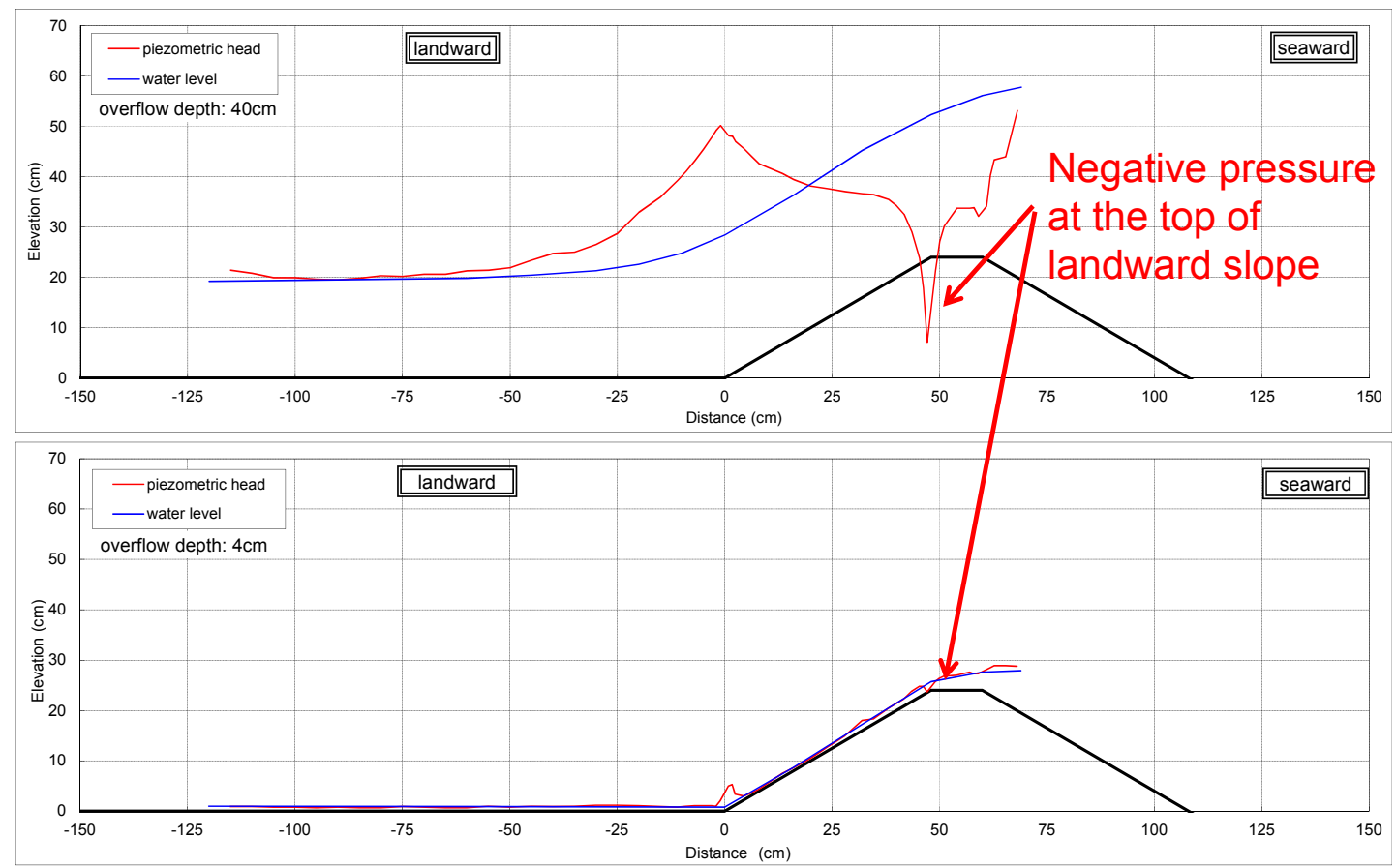

Figure 8. Cross-shore distribution of water levels and piezometric heads at the peak of overflow (left: overflow depth $40 \mathrm{~cm}$; right: overflow depth $4 \mathrm{~cm}$ ). 
Another experiment also provided useful insight on this failure pattern. Figure 9 shows video images of the physical experiments on landward armor failure. The height of the model dike was $24 \mathrm{~cm}$, and the overflow depth was $40 \mathrm{~cm}$. Landward armor of $2 \mathrm{~cm}$ thick was installed on the dike body. At $65 \mathrm{~s}$ after the start of the overflow, the landward armor was turned over from the top. The negative pressure at the top of the landward armor affected this failure.

The failure process from the crown or the top of the landward armor can be summarized as shown in Fig. 10. The landward armor or crown armor floated away, which caused the dike body to wash away.

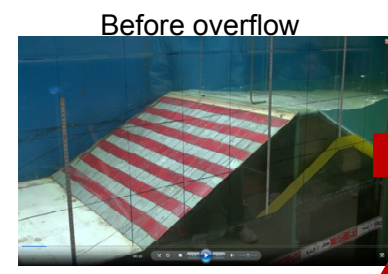

65 sec after
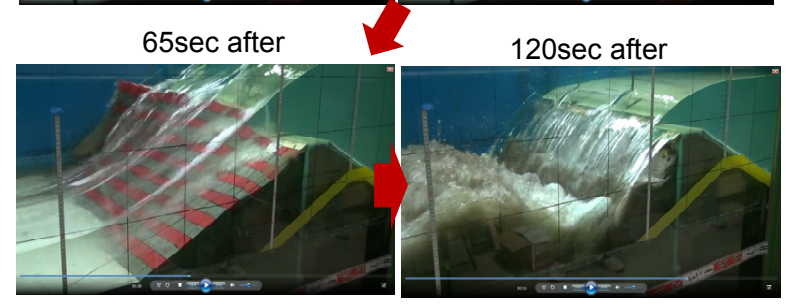

Figure 9. Example of failure from the top of the landward slope (dike height: $36 \mathrm{~cm}$, overflow depth: $40 \mathrm{~cm}$ ).

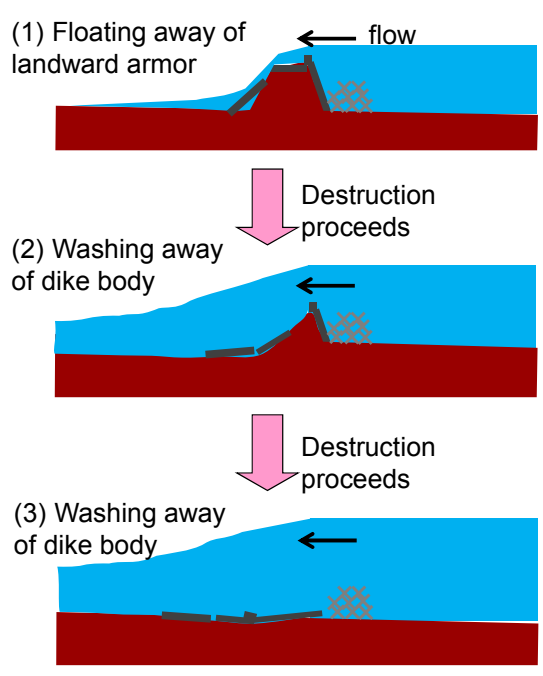

Figure 10. Process of failure from the crown or the top of the landward armor.

\section{Parapet failure induced by tsunami runup}

Concrete parapets were installed along the shoreline to mitigate wind-wave overtopping, but some of the parapets were broken by tsunami runup. As shown in Fig. 11, a broken parapet lies landward on the Toyoma Coast where tsunami inundation height was about $11 \mathrm{~m}$, and the parapet height was $5.4 \mathrm{~m}$.

This pattern may occur if shear stress induced by the wave force acting on the parapet during tsunami overtopping is larger than the shear strength of the parapet joints, as shown in Fig. 12.

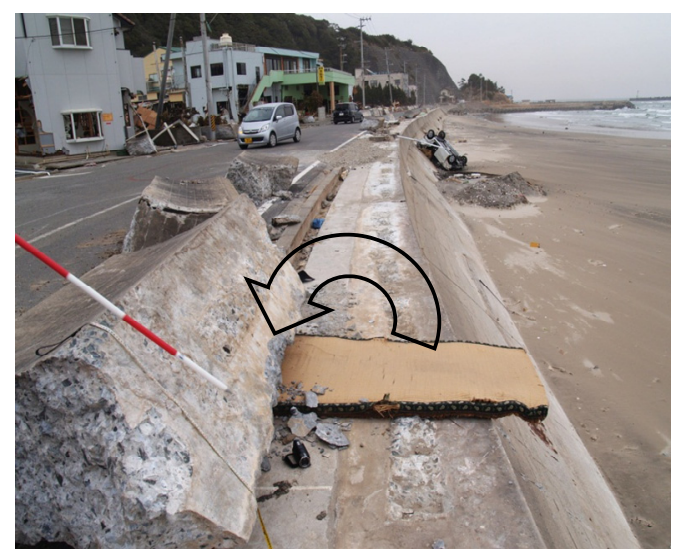

Figure 11. Parapet failure on Toyoma Coast, Fukushima Prefecture.
(1) Wave force acting on the parapet

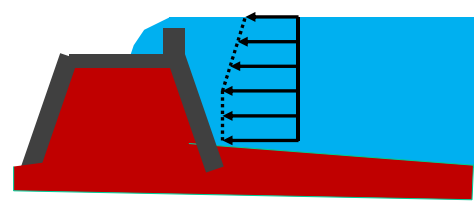

(2) Parapet break

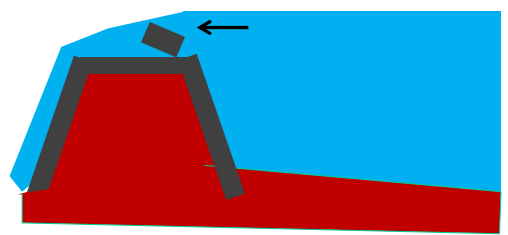

Figure 12. Process of parapet failure induced by tsunami runup.

\section{Failure from scouring at seaward toe}

Seaward flow over the coastal dike may cause scouring at the seaward toe of the dike. Although this pattern has already been pointed out in previous studies (e.g., Noguchi et al. 1997), it was also observed in the Great East Japan Earthquake. On the Mizuumi Coast, Iwate Prefecture, the seaward 
armor of the coastal dike was broken and the dike body was washed away, as shown in Fig. 13. The failure process can be summarized as shown in Fig. 14. Seaward flow during tsunami drawdown caused scouring at the seaward toe of the coastal dike and revetment. Scouring at the landward toe affected the stability of the seaward armor, resulting in floating away of seaward armor and breaching of the dike.

(1) Scouring at seaward toe

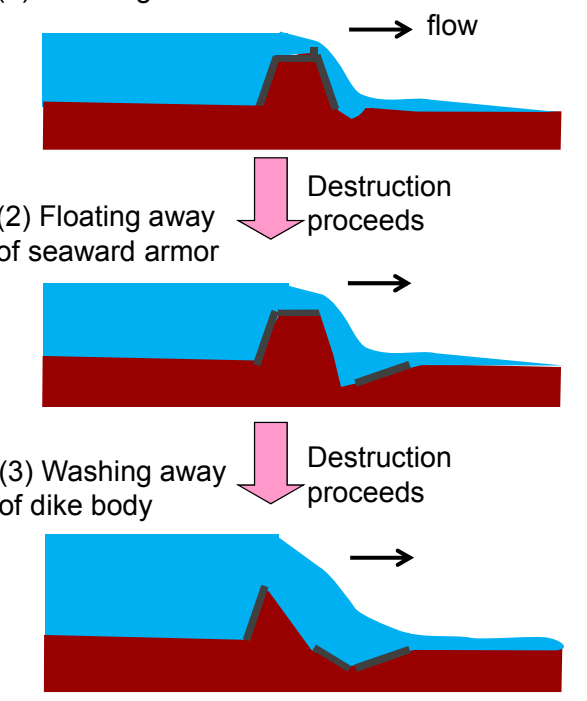

Figure 13. Failure of seaward armor on Mizuumi Coast, Iwate Prefecture.

Figure 14. Process of failure from scouring at seaward toe.

5. Parapet failure induced by tsunami drawdown

Similarly to tsunami runup, tsunami drawdown also results in wave forces acting on the parapet, leading to parapet failure. Parapets are designed not for tsunami forces from the land but for wave forces from the sea.

\section{Seawall overturning by tsunami runup}

Figure 15 shows overturning of the seawall on the Ryoishi Coast, Iwate Prefecture, where tsunami inundation height was $21 \mathrm{~m}$ and the height of the seawall was $9.2 \mathrm{~m}$. This pattern may occur if the overturning moment induced by the wave force on the seawall during tsunami runup or drawdown is larger than the resistance moment due to the weight of the seawall, as shown in Fig. 16.

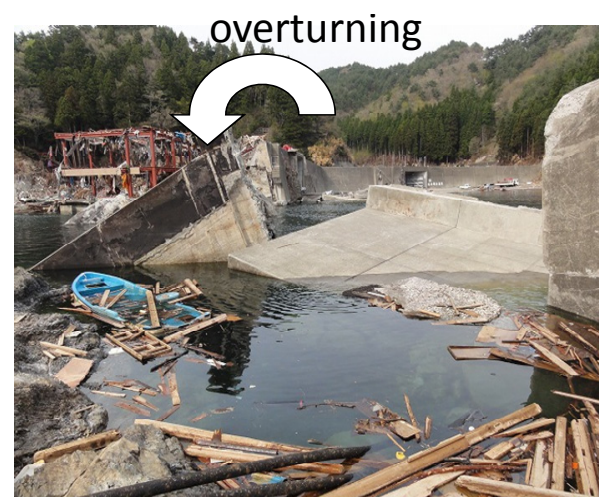

Figure 15. Overturning of seawall on Ryoishi Coast, Iwate Prefecture.
(1) Wave force acting on the seawall
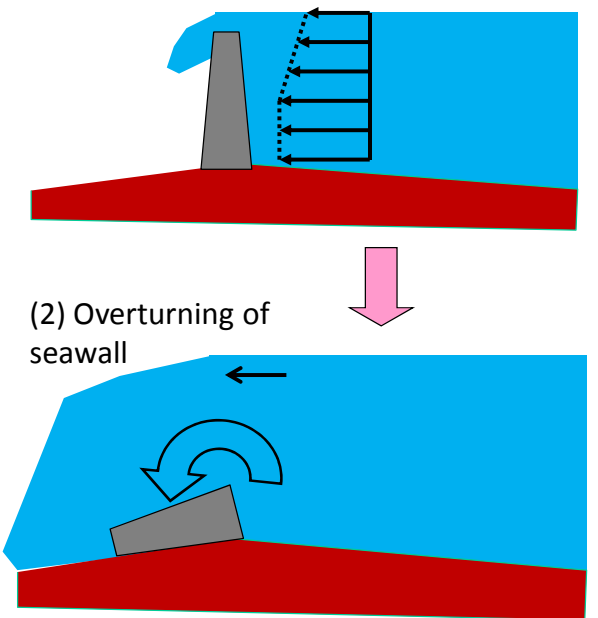

Figure 16. Process of seawall overturning. 
7. Seawall overturning by tsunami drawdown

Wave forces act on the seawall also during the tsunami drawdown stage. As with the previous pattern, seawall failure may occur due to the overturning moment.

8. Mainly by seismic motion

Tsunami was the dominant force for coastal dike failure in the earthquake; however, some coastal dikes and revetments were damaged mainly by seismic motion and ground liquefaction. For example, crown armor on the Yotsukura Coast sank about $40 \mathrm{~cm}$, and a coastal revetment on the Ichikawa Coast was cracked, as shown in Fig. 17. The same type of failure was suspected on the coast along Iwate and Miyagi Prefectures. However, on the coasts where tsunami waves were relatively high, the damage caused by seismic motion would likely be hidden by tsunami damage after the earthquake.
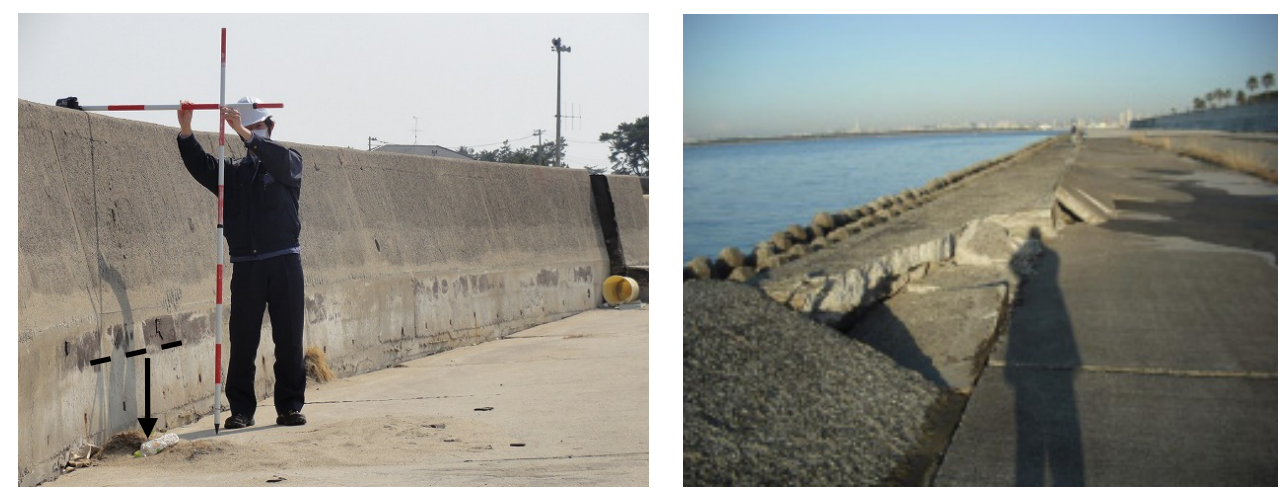

Figure 17. Examples of damage mainly caused by seismic motion (left: Yotsukura Coast, Fukushima Prefecture; right: Ichikawa Coast, Chiba Prefecture).

\section{Proportion of Each Failure Pattern along the Total Length of Damaged Coastal Dike}

We judged the failure patterns for each coast between Aomori Prefecture and Chiba Prefecture, and calculated the proportion of each failure pattern along the length of damaged coastal dike. The total length of damaged dike for this calculation was $99 \mathrm{~km}$.

It was difficult to identify all failure patterns for all the coasts because (1) important clues and indications were completely washed away in many areas and (2) more than one mechanism might have been complexly generated. Therefore, this is a rough result, but is considered to represent the basic characteristics of coastal dike failure.

As shown in Fig. 18, failure from scouring at the landward toe is the dominant failure pattern at $49.2 \%$. The proportion of parapet failure induced by tsunami drawdown is relatively large at $9.2 \%$. Failure from the crown or the top of the landward slope and failure from scouring at the seaward slope each accounts for about $4 \%$.

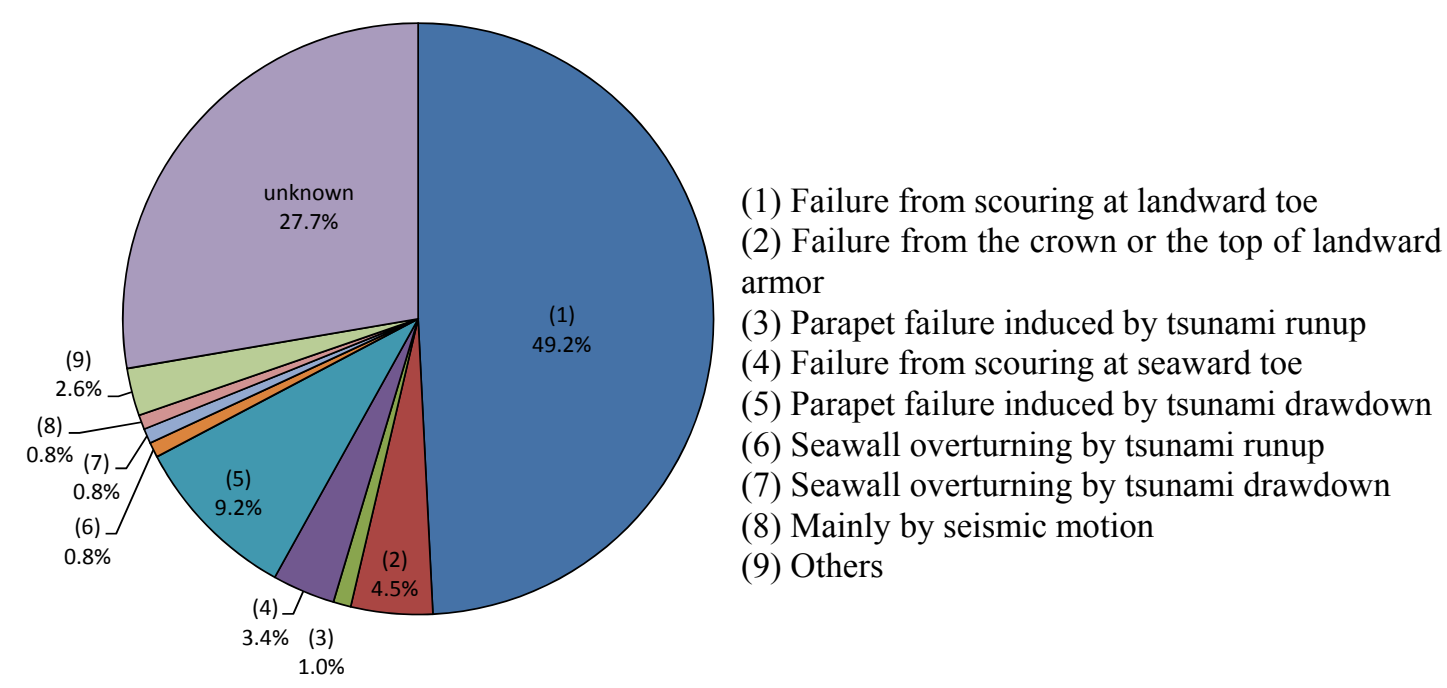

Figure 18. Proportion of each failure pattern along the length of damaged coastal dike. 


\section{BASIC PRINCIPLES ON RESTORATION OF COASTAL DIKE}

After the Great East Japan Earthquake Tsunami, the Japanese government established the Study Committee for Tsunami Countermeasures for Coastlines. In November 2011, the Committee released a report on the basic principles for restoration of coastal dikes damaged by the earthquake. The report included the procedure for setting the water level of the design tsunami, basic ideas on resilient structures for coastal dikes, and considerations for anti-seismic measures. Major statements in the report are as follows:

- The height of the coastal dike should be designed for tsunami that arrives at a frequency of once every several decades up to between 100 and 200 years.

- Devices on the structures aimed at disaster mitigation in the hinterland are implemented to extend the time, even slightly, until the destruction of a coastal dike, or to reduce the risk, even slightly, of complete destruction of a coastal dike, even if a tsunami exceeds the design level and flows over the coastal dike.

- Effective devices for resilient structures include protection for the landward toe to prevent scouring, increasing the thickness of armoring on the slopes and crown of coastal dikes, and avoiding parapets.

- Anti-seismic countermeasures should be taken in view of an earthquake that causes a tsunami as large as the design tsunami.

Since the height of the coastal dike will be lower than that of the highest-class tsunami, resilience to tsunami overflow is important. Therefore, based on the report, resilient structures for coastal dikes are being studied by research institutes in Japan. We recently released preliminary reports on resilient structures for coastal dikes (River Research Department, National Institute for Land and Infrastructure Management, 2012). As shown in Fig. 19, a large foundation at the landward slope toe and a sequence of blocks with notches on the top and the bottom as landward slope armor were proposed in the reports based on the results of hydraulic experiments and calculations. The proposed structures were examined through large-scale hydraulic model experiments, and have been adopted in restoration works in the southern part of the Sendai Plain.

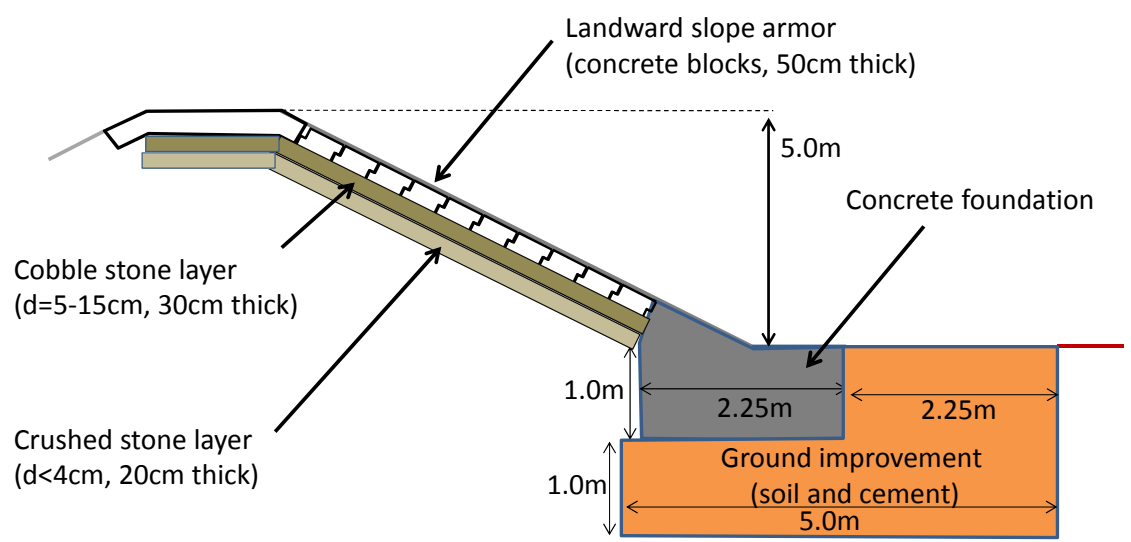

Figure 19. Proposed resilient structures for coastal dike.

\section{CONCLUSIONS}

Based on the results of field surveys, coastal dike failure in the Great East Japan Earthquake was classified into eight patterns. The results of hydraulic model experiments related to major failure patterns reinforced the proposed failure processes. In addition, the aggregated length of each failure pattern showed that failure from scouring at the landward toe is the dominant failure pattern.

\section{ACKNOWLEDGMENTS}

This study was conducted as a part of the Study Committee for Tsunami Countermeasures on Coastlines, which was established by the Japanese government. We express our deep appreciation to the prefectures for providing the data on coastal facilities. Tsunami inundation height measured by the 2011 Tohoku Earthquake Tsunami Joint Survey Group (http://www.coastal.jp/ tsunami2011/) was used in this study. 


\section{REFERENCES}

Kato, F., S. Inagaki, and M. Fukuhama. 2007. Wave force on coastal dike due to tsunami, Proceedings of the 30th International Conference on Coastal Engineering, ASCE, 5150-5161.

Kato, F., K. Noguchi, Y. Suwa, T. Sakagami, and Y. Sato. 2012. Field survey on tsunami-induced topographical change, Journal of Japan Society of Civil Engineers, Ser. B3 (Ocean Engineering), Vol. 68, No. 2 (in press).

Mikami, T., T. Shibayama, M. Esteban, and R. Matsumaru. 2012. Field survey of the 2011 Tohoku Earthquake and Tsunami in Miyagi and Fukushima Prefectures, Coastal Engineering Journal, 54(1), 1250011.

Nishimura H., and K. Horikawa. 1979. Scouring at the toe of a seawall due to tsunami drawdown, Proceedings of the 26th Coastal Engineering Conference, JSCE, 210-214 (in Japanese)

Noguchi, K., S. Sato, and S. Tanaka. 1997. Large-scale experiments on tsunami overtopping and bed scour around coastal revetment, Proceedings of Coastal Engineering, JSCE, 44, 296-300 (in Japanese).

Ogasawara, T., Y. Matsubayashi, S. Sakai, and T. Yasuda. 2012. Characteristics of the 2011 Tohoku Earthquake and Tsunami and its impact on the northern Iwate Coast, Coastal Engineering Journal, 54(1), 1250003.

River Research Department, National Institute for Land and Infrastructure Management. 2012. Preliminary report on resilient structures of coastal dike, http://www.nilim.go.jp/lab/fcg/labo/ 02_02.html (in Japanese).

Shuto, N. 2009. Damages to coastal structures by tsunami-induced currents in the past, Journal of Disaster Research, 4(6), 462-468. 